\title{
PERLINDUNGAN HUKUM TERHADAP PELAKU TINDAK PIDANA BERDASARKAN SISTEM PERADILAN PIDANA INDONESIA
}

\author{
Hasan Basri \\ Mahasiswa Program Magister Ilmu Hukum, Pascasarjana Universitas Airlangga, Surabaya
}

Email Korespondensi: hbasri193@gmail.com

\begin{abstract}
Abstrak. Penelitian ini bertujuan untuk menguraikan upaya hukum bagi para terdakwa atau terpidana sebagai bentuk persamaan di hadapan hukum berdasarkan peraturan perundangundangan. Metode yang digunakan dalam penelitian ini adalah metode penelitian yuridis normatif yang bersifat deskriptif kualitatif. Teknik pengumpulan bahan hukum dalam penelitian ini adalah teknik studi kepustakaan. Adapun metode analisis dilakukan dengan cara mengidentifikasi secara sistematis serta menghubungkan antar ketentuan yang terdapat dalam bahan hukum primer. Hasil penelitian menunjukkan bahwa upaya hukum bagi para terdakwa atau terpidana sebagai bentuk persamaan di hadapan hukum berdasarkan peraturan perundang-undangan, terdiri dari upaya hukum biasa dan upaya hukum luar biasa. Adapun upaya hukum biasa, meliputi perlawanan, banding, dan kasasi. Sedangkan upaya hukum luar biasa, meliputi pemeriksaan kasasi demi kepentingan hukum dan peninjauan kembali. Upaya hukum juga merupakan manifestasi dari fungsi hukum, dimana untuk melindungi manusia dalam masyarakat, bangsa, dan negara. Selain itu baik jiwa dan raga maupun hak individu yaitu hak asasinya, hak kebendaanya, maupun hak perorangannya. Disarankan agar baik aparat penyelenggara hukum maupun masyarakat, khususnya para pelaku tindak pidana agar memahami hak dan kewajiban yang telah diatur dalam UU No. 8 Tahun 1981, UU No. 3 Tahun 2009, dan UU No. 48 Tahun 2009 terkait perlindungan hukum terhadap pelaku tindak pidana berdasarkan sistem peradilan pidana Indonesia.
\end{abstract}

Kata Kunci:

Pelaku Tindak Pidana;

Perlindungan Hukum; Sistem Peradilan Pidana.

artikel dengan akses terbuka dibawah lisensi CC BY -4.0

\section{PENDAHULUAN}

Hukum merupakan hal yang esensial dalam eksistensi negara dan menjadi perhatian penting karena dapat melindungi masyarakat dari penguasa tirani atau totaliter. Selain itu dapat mengatasi orang atau kelompok tertentu yang berperilaku anarkis. ${ }^{1}$ Menanggapi pemahaman tersebut, hukum merupakan wadah untuk melindungi

${ }^{1}$ Harold Joseph Berman (Ed.) (1961). Talks on American Law: A Series of Broadcasts to Foreign Audiences by Members of the Harvard Law School Faculty. New York: Vintage Books, hlm. 2. 
masyarakat. Oleh karena itu suatu Negara akan memiliki nilai-nilai yang beradab jika Negara itu berdasarkan hukum, dan hukum di Indonesia adalah hal yang esensial, sebagaimana berdasarkan Pasal 1 ayat (3) Undang-Undang Dasar Negara Republik Indonesia Tahun 1945 (selanjutnya disebut UUD NRI Tahun 1945), mengatur bahwa "Negara Indonesia adalah negara hukum".

Oleh karena itu, Negara memiliki peran penting dalam melindungi hak-hak rakyatnya secara adil dan beradab karena salah satu kunci kekuatan suatu Negara tidak terlepas dari bagaimana Negara dapat melindungi rakyatnya dari segala ancaman baik fisik maupun ancaman lainnya. Artinya ada perlindungan hak asasi manusia (HAM) yang harus ditekankan secara fundamental di dalam negara. ${ }^{2}$

HAM merupakan salah satu hak yang dijunjung tinggi dan paling dihormati di berbagai negara di seluruh dunia, termasuk Indonesia. HAM merupakan hak paling mendasar yang dimiliki manusia sebagai anugerah dari Tuhan Yang Maha Esa, sebagaimana berdasarkan Pasal 10 Deklarasi Universal tentang Hak Asasi Manusia (The Universal Declaration of Human Rights) Tahun 1948, mengatur bahwa:

"Everyone is entitled in full equality to a fair and public hearing by an independent and impartial tribunal, in the determination of his rights and obligations and of any criminal charge against him (Setiap orang dalam persamaan yang penuh berhak atas pengadilan yang adil dan terbuka oleh pengadilan yang bebas dan tidak memihak, dalam menetapkan hak dan kewajiban-kewajibannya serta dalam setiap tuntutan pidana yang dijatuhkan kepadanya.)"

Adapun berdasarkan Pasal 28D ayat (1) UUD NRI Tahun 1945, mengatur bahwa "Setiap orang berhak atas pengakuan, jaminan, perlindungan, dan kepastian hukum yang adil serta perlakuan yang sama dihadapan hukum".

Ketentuan di atas merupakan yang paling mendasar bagi HAM, dimana setiap orang memiliki persamaan hak di hadapan hukum dan harus ditegakkan. Hal inilah yang dikenal sebagai asas persamaan di hadapan hukum (equality before the law).

Fungsi hukum adalah melindungi manusia dalam masyarakat, bangsa, dan negara. Selain itu baik jiwa dan raga maupun hak individu yaitu hak asasinya, hak kebendaanya, maupun hak perorangannya. Ini juga berlaku untuk narapidana di lembaga pemasyarakatan selama masa hukuman mereka. Salah satu fungsi lembaga pemasyarakatan adalah memberikan pembinaan baik pengetahuan dan keterampilan agar narapidana memiliki bekal yang berguna saat kembali berbaur di lingkungan masyarakat. $^{3}$

\footnotetext{
${ }^{2}$ Heru Santosa. (2011). Ancaman terhadap Dasar Negara "Pancasila" bagi Rakyat Indonesia dalam Berbangsa dan Bernegara. Humanika: Kajian Ilmiah Mata Kuliah Umum, Universitas Negeri Yogyakarta, 11(2), hlm. 8.

${ }^{3}$ Philipus M. Hadjon. (1987). Perlindungan Hukum Bagi Rakyat di Indonesia: Sebuah Studi tentang Prinsip-Prinsipnya, Penanganannya oleh Peradilan dalam Lingkungan Peradilan Umum dan Pembentukan Peradilan Administrasi Negara. Surabaya: PT. Bina Ilmu, hlm. 39.
} 
Dalam penegakan hukum pidana di Indonesia tidak lepas dari ketentuan hukum pidana materiil dan hukum pidana formil. Hukum pidana materiil umumnya diatur dalam Undang-Undang Republik Indonesia Nomor 1 Tahun 1960 tentang Perubahan Kitab Undang-Undang Hukum Pidana (selanjutnya disebut UU No. 1 Tahun 1960) dan peraturan perundang-undangan yang memuat ketentuan pidana. Begitu pula hukum pidana formal yang umumnya diatur dalam Undang-Undang Republik Indonesia Nomor 8 Tahun 1981 tentang Hukum Acara Pidana (selanjutnya disebut UU No. 8 Tahun 1981) dan peraturan perundang-undangan yang memuat ketentuan acara pidana.

Berdasarkan dua aturan hukum yang merupakan hukum positif di Indonesia, dimana baik UU No. 1 Tahun 1960 dan UU No. 8 Tahun 1981 harus dapat dijadikan pedoman bagi aparat penegak hukum dalam menangani pelaku tindak pidana. ${ }^{4}$

Setiap pelaku tindak pidana memiliki hak sebagaimana berdasarkan Pasal 1 angka 12 UU No. 8 Tahun 1981:

"Upaya hukum adalah hak terdakwa atau penuntut umum untuk tidak menerima putusan pengadilan yang berupa perlawanan atau banding atau kasasi atau hak terpidana untuk mengajukan permohonan peninjauan kembali dalam hal serta menurut cara yang diatur dalam undang-undang ini."

Dari ketentuan di atas dapat disimpulkan bahwa yang dimaksud dengan upaya hukum yang sebenarnya tidak lain adalah tata cara perlawanan, banding, kasasi, dan upaya hukum peninjauan kembali putusan pengadilan atau Majelis Hakim. ${ }^{5}$

Lebih lanjut, pelaku tindak pidana dengan status baik tersangka maupun terdakwa juga memiliki hak sebagaimana diatur dalam Pasal 50 sampai dengan Pasal 68 UU No. 8 Tahun 1981. Namun demikian, banyak orang seringkali tidak memahami hakhaknya ketika dihadapkan pada hukum atau didakwa melakukan suatu tindak pidana. Mereka sering menyia-nyiakan haknya. Bahkan tragisnya, mereka mengira jika sudah menjadi terdakwa atau terpidana, tidak ada lagi yang bisa dilakukan. Hal seperti ini sering kita jumpai pada masyarakat yang kurang memahami hak-haknya.

Adanya upaya hukum yang diberikan oleh peraturan perundang-undangan tidak lain adalah untuk melindungi hak-hak para pelaku tindak pidana jika dihadapkan pada putusan yang keliru, tidak memuaskan atau putusan yang menyudutkan terdakwa. ${ }^{6}$ Upaya hukum merupakan salah satu bentuk perlindungan terhadap hak-hak warga negara ketika berhadapan dengan hukum, baik dalam proses persidangan maupun setelah adanya putusan yang berkekuatan hukum tetap sampai dengan pelaksanaan

\footnotetext{
${ }^{4}$ M. Yahya Harahap. (2012). Pembahasan Permasalahan dan Penerapan KUHAP: Pemeriksaan Sidang Pengadilan, Banding, Kasasi dan Peninjauan Kembali (Edisi 2). Jakarta: Sinar Grafika, hlm. 35.

${ }^{5}$ Priscilia Singal. (2013). Fungsi Lembaga Peninjauan Kembali dalam Sistem Peradilan Pidana di Indonesia. Lex et Societatis, Universitas Sam Ratulangi, 1(2), hlm. 112.

${ }^{6}$ Fajar Laksono Soeroso. (2014). Aspek Keadilan dalam Sifat Final Putusan Mahkamah Konstitusi. Jurnal Konstitusi, Mahkamah Konstitusi RI, 11(1), hlm. 82.
} 
hukuman bagi terpidana. ${ }^{7}$ Perlindungan hukum tetap ada bagi terdakwa maupun terpidana. $^{8}$

Beberapa kasus yang terjadi, Majelis Hakim terkadang mengabaikan prinsip yang diatur dalam peraturan perundang-undangan. Seharusnya terdakwa sudah mendapatkan kepastian hukum dari Majelis Hakim melalui pengarahan untuk melanjutkan tahap persidangan selanjutnya sebagai upaya perlindungan hukum. Apalagi, hak hukum tersebut diatur dalam peraturan perundang-undangan sehingga terdakwa atau terpidana dapat mengambil tindakan hukum untuk mendapatkan keadilan.

Pengadilan melakukan beberapa kasus penolakan karena berbagai alasan. Misalnya dalam kasus Korupsi Bupati Natuna, setelah putusan pengadilan bersifat tetap, Bupati Natuna melakukan upaya hukum peninjauan kembali, namun upaya hukumnya ditolak. $^{9}$

Berdasarkan uraian di atas, maka penelitian ini bertujuan untuk menguraikan upaya hukum bagi para terdakwa atau terpidana sebagai bentuk persamaan di hadapan hukum berdasarkan peraturan perundang-undangan. Adapun manfaat dari penelitian tersebut adalah untuk memberikan pemahaman kepada para terdakwa atau terpidana terkait hak-hak perlindungan hukum.

\section{METODE}

Metode yang digunakan dalam penelitian ini adalah metode penelitian yuridis normatif. Hal ini sesuai dengan karakter ilmu hukum yang bersifat preskriptif sehingga sering dikatakan bahwa ilmu hukum merupakan ilmu yang normatif. Penelitian hukum adalah suatu proses untuk menemukan aturan hukum, prinsip-prinsip hukum, maupun doktrin-doktrin hukum guna menjawab isu hukum yang dihadapi. ${ }^{10}$ Bahan hukum yang digunakan dalam penelitian ini, adalah sebagai berikut:

1. Bahan hukum primer, yaitu bahan-bahan hukum yang mengikat, antara lain:

a. UU No. 8 Tahun 1981 tentang Hukum Acara Pidana;

b. UU No. 14 Tahun 1985 tentang Mahkamah Agung;

c. UU No. 5 Tahun 2004 tentang Perubahan Atas Undang-Undang Nomor 14 Tahun 1985 tentang Mahkamah Agung;

d. UU No. 3 Tahun 2009 tentang Perubahan Kedua Atas Undang-Undang Nomor 14 Tahun 1985 tentang Mahkamah Agung;

e. UU No. 48 Tahun 2009 tentang Kekuasaan Kehakiman.

${ }^{7}$ Rifandy Ritonga. (2016). Analisis Pengujian Pengaduan Konstitusional (Constitutional Complaint) pada Mahkamah Konstitusi Indonesia sebagai Salah Satu Upaya Perlindungan Hak-Hak Warga Negara. Keadilan Progresif, Universitas Bandar Lampung, 7(1), hlm. 10.

${ }^{8}$ Gabriela K. Kaawoan. (2017). Perlindungan Hukum terhadap Terdakwa dan Terpidana sebagai Pelaku Tindak Pidana Pembunuhan. Lex Administratum, Universitas Negeri Semarang, 5(1), hlm. 127.

${ }^{9}$ Willy Widianto. (2010, 20 Oktober). PK Mantan Bupati Natuna Ditolak MA. Dalam Tribunnews.com. Diakses pada tanggal 27 Desember 2020.

${ }^{10}$ Nurul Qamar \& Farah Syah Rezah. (2020). Metode Penelitian Hukum: Doktrinal dan Non-Doktrinal. Makassar: CV. Social Politic Genius (SIGn), hlm. 13. 
2. Bahan hukum sekunder, yaitu bahan yang memberikan penjelasan mengenai bahan hukum primer, seperti buku-buku literature, hasil-hasil penelitian, hasil karya dari kalangan hukum atau praktisi hukum yang ada kaitannya dengan perlindungan hukum terhadap pelaku tindak pidana berdasarkan sistem peradilan pidana Indonesia.

Untuk memperoleh bahan hukum yang dibutuhkan dalam penelitian ini, maka digunakan teknik pengumpulan data studi kepustakaan, yakni menginventarisasi, membaca dan menganalisis bahan-bahan hukum, baik bahan hukum primer maupun bahan hukum sekunder. ${ }^{11}$

Bahan hukum yang telah terkumpul kemudian diolah secara deskriptif kualitatif. Adapun metode analisis dilakukan dengan cara mengidentifikasi secara sistematis serta menghubungkan antar ketentuan yang terdapat dalam bahan hukum primer. ${ }^{12}$

\section{HASIL DAN PEMBAHASAN}

Secara umum upaya hukum adalah suatu cara yang diberikan oleh peraturanperundang-undangan kepada seseorang atau badan hukum dalam kasus tertentu terhadap putusan pengadilan. Upaya perlindungan hukum dalam teori dan praktik hukum terdapat 2 (dua) macam, yaitu upaya hukum biasa dan upaya hukum luar biasa. Perbedaan antara keduanya adalah bahwa dalam upaya hukum biasa, eksekusi ditangguhkan kecuali dakwaan diberikan terhadap suatu keputusan. Sebaliknya, upaya hukum luar biasa tidak menangguhkan eksekusi.

\section{A. Upaya Hukum Biasa}

\section{Perlawanan (Verzet)}

Perlawanan (verzet) sebagai bentuk perlindungan hukum jarang dibahas dalam memahami perlindungan hukum. Kita sering kali lebih memahami terkait perlindungan hukum tentang banding dan kasasi, sebagaimana berdasarkan Pasal 1 angka 12 UU No. 8 Tahun 1981, menjelaskan bahwa:

"Upaya hukum adalah hak terdakwa atau penuntut umum untuk tidak menerima putusan pengadilan yang berupa perlawanan atau banding atau kasasi atau hak terpidana untuk mengajukan permohonan peninjauan kembali dalam hal serta menurut cara yang diatur dalam undang-undang ini."

Dari ketentuan di atas, dapat dipahami bahwa upaya hukum tersebut memiliki unsur-unsur, antara lain yaitu:

a. Hak Terdakwa untuk tidak menerima putusan pengadilan yang berupa:

\footnotetext{
${ }^{11}$ Syarif Saddam Rivanie. (2020). Pengadilan Internasional dalam Memberantas Tindak Pidana Terorisme: Tantangan Hukum dan Politik. Sovereign: Jurnal Ilmiah Hukum, CV. Social Politic Genius (SIGn), 2(3), hlm. 18.

${ }^{12}$ N. Nasrullah. (2020). Putusan Hakim terhadap Pemberian Sanksi di Bawah Batas Minimal pada Tindak Pidana Narkotika. SIGn Jurnal Hukum, CV. Social Politic Genius (SIGn), 2(1), hlm. 4.
} 

1) Perlawanan;
2) Banding;
3) Kasasi;

b. Hak terpidana untuk mengajukan permohonan Peninjauan Kembali.

Selanjutnya, perlawanan (verzet), sebagaimana berdasarkan Pasal 156 ayat (4) UU No. 8 Tahun 1981, mengatur bahwa:

"Dalam hal perlawanan yang diajukan oleh terdakwa atau penasihat hukumnya diterima olah Pengadilan Tinggi, maka dalam waktu empat belas hari, Pengadilan Tinggi dengan surat penetapannya membatalkan putusan Pengadilan Negeri dan memerintahkan Pengadilan Negeri yang berwenang untuk memeriksa perkara itu."

Berdasarkan Pasal 156 ayat (5) huruf a UU No. 8 Tahun 1981, mengatur bahwa:

"Dalam hal perlawanan diajukan bersama-sama dengan permintaan banding oleh terdakwa atau penasihat hukumnya kepada Pengadilan Tinggi, maka dalam waktu empat belas hari sejak ia menerima perkara dan membenarkan perlawanan terdakwa, Pengadilan Tinggi dengan keputusan membatalkan keputusan Pengadilan Negeri yang bersangkutan dan menunjuk Pengadilan Negeri yang berwenang."

Lebih lanjut, perlawanan (verzet) diatur dalam BAB XVI Pemeriksaan Sidang Pengadilan, Bagian Keenam Acara Pemeriksaan Cepat, Paragraf 2 Acara Pemeriksaan Perkara Pelanggaran Lalu Lintas Jalan, mulai dari Pasal 211 sampai dengan Pasal 216 UU No. 8 Tahun 1981.

Berdasarkan Pasal 211 UU No. 8 Tahun 1981, mengatur bahwa:

"Yang diperiksa menurut acara pemeriksaan pada Paragraf ini ialah perkara pelanggaran tertentu terhadap peraturan perundangundangan lalu lintas jalan."

Berdasarkan Pasal 212 UU No. 8 Tahun 1981, mengatur bahwa:

"Untuk perkara pelanggaran lalu lintas jalan tidak diperlukan berita acara pemeriksaan, oleh karena itu catatan sebagaimana dimaksud dalam Pasal 207 ayat (1) huruf a segera diserahkan kepada pengadilan selambat-lambatnya pada kesempatan hari sidang pertama berikutnya."

Berdasarkan Pasal 213 UU No. 8 Tahun 1981, mengatur bahwa "Terdakwa dapat menunjuk seorang dengan surat untuk mewakilinya di sidang".

Dari ketentuan di atas, yang dimaksud dengan upaya hukum perlawanan (verzet) adalah perbuatan hukum yang dilakukan oleh terdakwa dalam perkara pelanggaran lalu lintas dan tidak hadir dalam pemeriksaan perkara. Selain itu, putusan pengadilan berupa pidana perampasan kebebasan, dalam hal ini pidana penjara. ${ }^{13}$ Dengan kata lain, perlawanan (verzet) adalah upaya

${ }^{13}$ Syahrul Sitorus. (2018). Upaya Hukum dalam Perkara Perdata (Verzet, Banding, Kasasi, Peninjauan Kembali dan Derden Verzet). Hikmah, Sekolah Tinggi Agama Islam Sumatera, 15(1), hlm. 64. 
hukum yang dilakukan oleh terdakwa yang dihukum penjara karena tindak pidana lalu lintas dan tidak hadir pada saat diperiksa di pengadilan.

Dari uraian di atas, maka persyaratan upaya hukum berupa perlawanan (verzet), antara lain:

a. Perkara tindak pidana pelanggaran lalu-lintas;

b. Terdakwa tidak hadir pada pemeriksaan perkara;

c. Pidana yang dijatuhkan adalah pidana penjara;

d. Terdakwa mengajukan perlawanan kepada Pengadilan Negeri yang memutus perkara tersebut;

e. Dengan adanya perlawanan ini, putusan pidana penjara menjadi gugur dan terdakwa dipanggil untuk diperiksa kembali;

f. Jika terdakwa hadir, maka terdakwa akan diperiksa dan dijatuhi sanksi pidana berupa:

1) Pidana denda, dengan upaya hukum berupa banding ke Pengadilan Tinggi,

2) Pidana penjara, dengan upaya hukum berupa banding ke Pengadilan Tinggi.

g. Setelah dipanggil, jika terdakwa masih berhalangan hadir, maka hukuman penjara yang dijatuhkan sangat kuat. Dengan putusan tersebut, terdakwa dapat mengajukan permohonan banding ke Pengadilan Tinggi.

\section{Banding}

Banding adalah salah satu bentuk upaya hukum yang merupakan hak terdakwa berdasarkan UU No. 8 Tahun 1981 yang dimana terdakwa tidak setuju dengan putusan pengadilan. ${ }^{14}$ Banding adalah upaya hukum yang dapat diambil para pihak untuk memeriksa kembali putusan pengadilan di tingkat pertama. ${ }^{15}$ Upaya hukum banding juga dapat ditujukan untuk mengoreksi putusan pengadilan tingkat pertama jika ditemukan kesalahan atau kelalaian dalam memberikan putusan. ${ }^{16}$ Tujuan koreksi adalah kembali pada ketentuan hukum dan peraturan perundang-undangan yang sebenarnya sehingga pemeriksaan dan putusan peradilan di tingkat pertama benar-benar akomodatif dan proporsional berdasarkan peraturan perundang-undangan yang berlaku. ${ }^{17}$ Selain itu, tujuan dari upaya hukum banding adalah untuk mencegah kesewenang-wenangan atau penyalahgunaan jabatan oleh pengadilan tingkat pertama. Dapat disimpulkan bahwa upaya hukum banding, yaitu selain mengoreksi kesalahan pada tingkat pertama, juga melakukan pencegahan

\footnotetext{
${ }^{14}$ Luhut M. P. Pangaribuan. (2002). Hukum Acara Pidana: Surat-Surat Resmi di Pengadilan oleh Advokat Praperadilan, Eksepsi, Pledoi, Memori Banding, Kasasi, Peninjauan Kembali. Jakarta: Djambatan, hlm. 76.

${ }^{15}$ Bilryan Lumempouw. (2013). Hak Terdakwa Melakukan Upaya Hukum dalam Proses Peradilan Pidana. Lex Crimen: Jurnal Elektronik Bagian Hukum Pidana, Universitas Sam Ratulangi, 2(3), hlm. 188.

${ }^{16} J a n p a t a r$ Simamora. (2014). Kepastian Hukum Pengajuan Kasasi oleh Jaksa Penuntut Umum terhadap Vonis Bebas. Jurnal Yudisial, Komisi Yudisial Republik Indonesia, 7(1), hlm. 8.

${ }^{17}$ Agus Maksum Mulyohadi. (2015). Disparitas Pidana Putusan Hakim atas Perkara Pidana Anak dalam Perspektif Perlindungan Hak-Hak Anak (Studi Kasus Pengadilan Negeri Boyolali Tahun 2009 - 2013). Jurnal Jurisprudence, Universitas Muhammadiyah Surakarta, 5(2), hlm. 132.
} 
dan kesewenang-wenangan serta penyalahgunaan jabatan serta pengawasan terhadap terwujudnya asas persamaan di hadapan hukum. ${ }^{18}$

Adapun dasar hukum dalam upaya hukum banding, antara lain yaitu:

a. BAB XVII Upaya Hukum Biasa, Bagian kesatu Pemeriksaan Tingkat Banding, mulai dari Pasal 233 sampai dengan Pasal 243 UU No. 8 Tahun 1981;

b. Pasal 23 dan Pasal 26 Undang-Undang Republik Indonesia Nomor 48 Tahun 2009 tentang Kekuasaan Kehakiman (selanjutnya disebut UU No. 48 Tahun 2009).

Beberapa poin penting di dalam ketentuan upaya hukum banding, antara lain yaitu:

a. Putusan pengadilan tingkat pertama, yang bukan merupakan pembebasan dari dakwaan atau pembebasan dari semua tuntutan hukum, dapat diajukan banding ke pengadilan tinggi oleh para pihak terkait, sebagaimana berdasarkan Pasal 67 UU No. 8 Tahun 1981 dan Pasal 26 UU No. 48 Tahun 2009.

b. Pada dasarnya merupakan pemeriksaan ulang atas apa yang telah diperiksa oleh Pengadilan Negeri. Artinya Pengadilan Negeri memeriksa kembali semua fakta tersebut sehingga pengadilan tinggi disebut Judex Factie.

c. Merupakan hak terdakwa dan/atau penuntut Umum, dimana:

1) Diajukan melalui Panitera Pengadilan Negeri;

2) Pengajuan banding diajukan selambat-lambatnya tujuh hari setelah putusan dijatuhkan, dalam hal ini Panitera Pengadilan Negeri akan menolak pengajuan tersebut jika lebih dari tujuh hari, sebagaimana berdasarkan Pasal 233 ayat (2) UU No. 8 Tahun 1981;

3) Selama perkara belum diputuskan di tingkat banding, pemohon dapat mencabut permohonannya setiap saat. Dengan pencabutan ini, tidak ada lagi pengajuan banding.

4) Memori banding maupun kontra memori banding tidak wajib diajukan.

d. Putusan banding (putusan Pengadilan Tinggi) dapat berupa:

1) Menguatkan putusan Pengadilan Negeri;

2) Mengubah putusan Pengadilan Negeri;

3) Membatalkan putusan Pengadilan Negeri, dalam hal ini Pengadilan Tinggi membuat putusan sendiri.

e. Putusan yang dapat diajukan upaya hukum banding meliputi:

1) Pemidanaan;

2) Putusan dalam acara pidana lalu lintas berupa pidana penjara, sebagaimana berdasarkan Pasal 214 ayat (8) UU No. 8 Tahun 1981;

3) Penolakan eksepsi yang diajukan Penasehat Hukum.

${ }^{18}$ M. Yahya Harahap. (2006). Pembahasan Permasalahan dan Penerapan KUHAP: Penyidikan dan Penuntutan. Jakarta: Sinar Grafika, hlm. 451. 
f. Putusan yang tidak dapat diajukan upaya hukum banding meliputi;

1) Pembebasan;

2) Lepas dari segala tuntutan hukum;

3) Sahnya penangkapan;

4) Tidak sahnya penangkapan;

5) Sahnya penahanan;

6) Tidak sahnya penahanan;

7) Sahnya penggeledahan;

8) Tidak sahnya penggeledahan;

9) Sahnya penyitaan;

10) Tidak sahnya penyitaan.

11) Sahnya penghentian penyidikan;

12) Tidak sahnya penghentian penyidikan;

13) Sahnya penghentian penuntutan;

14) Tidak sahnya penghentian penuntutan.

15) Putusan dalam acara pidana lalu lintas berupa pidana denda.

\section{Kasasi}

Kasasi adalah salah satu upaya hukum biasa di tingkat terakhir yang diperiksa oleh Mahkamah Agung. ${ }^{19}$ Kata kasasi dikenal dengan istilah "cassation", dalam bahasa Belanda "caesei" yang berarti pembatalan putusan pengadilan sebelumnya. ${ }^{20}$

Pemeriksaan kasasi dapat diajukan terhadap perkara pidana yang diputuskan pada tingkat terakhir oleh pengadilan selain Mahkamah Agung, kecuali terhadap putusan bebas. ${ }^{21}$ Kasasi tidak dapat dimohonkan atas putusan yang dikeluarkan oleh Mahkamah Agung, artinya putusan kasasi tidak dapat dikasasikan kembali, sebagai bentuk kepastian hukum terhadap putusan kasasi. ${ }^{22}$ Yang dimaksud kasasi adalah pembatalan atau pemecahan. ${ }^{23}$ Sedangkan maksud dari kasasi adalah agar putusan terakhir yang bertentangan dengan hukum dapat dibatalkan. ${ }^{24}$

\footnotetext{
${ }^{19}$ Putra Halomoan Hsb. (2015). Tinjauan Yuridis tentang Upaya-Upaya Hukum. Yurisprudentia: Jurnal Hukum Ekonomi, Institut Agama Islam Negeri Padangsidimpuan, 1(1), hlm. 45.

${ }^{20}$ Osman Simanjuntak. (1995). Teknik Penuntutan dan Upaya Hukum. Jakarta: Grasindo, hlm. 168.

${ }^{21}$ A. Adiwana \& Amalia Zakiyatu Faturrahmah. (2016). Argumentasi Penuntut Umum Mengajukan Kasasi terhadap Putusan Bebas Pengadilan Negeri Yogyakarta dalam Tindak Pidana Perbuatan Merugikan Pemiutang (Studi Putusan Mahkamah Agung Nomor 601K/PID/2013). Verstek, Universitas Sebelas Maret, 5(1), hlm. 7.

${ }^{22}$ Enrico Simanjuntak. (2013). Kewenangan Hak Uji Materil pada Mahkamah Agung RI. Jurnal Hukum dan Peradilan, Mahkamah Agung RI, 2(3), hlm. 353.

${ }^{23}$ Prianter Jaya Hairi. (2011). Antara Prinsip Peradilan Sederhana, Cepat dan Berbiaya Ringan dan Gagasan Pembatasan Perkara Kasasi. Negara Hukum: Membangun Hukum untuk Keadilan dan Kesejahteraan, Pusat Penelitian Badan Keahlian DPR RI, 2(1), hlm. 159.

${ }^{24}$ Christian Hadinata Tamusala. (2018). Upaya Hukum Kasasi terhadap Tindak Pidana Korupsi Menurut Undang-Undang Pokok Kekuasaan Kehakiman Nomor 48 Tahun 2009. Lex Crimen: Jurnal Elektronik Bagian Hukum Pidana, Universitas Sam Ratulangi, 7(4), hlm. 110.
} 
Adapun uraian hukum dalam upaya hukum kasasi sebagaimana berdasarkan peraturan perundang-undangan, antara lain sebagai berikut.

\section{a. UU No. 3 Tahun 2009 tentang Mahkamah Agung}

Berdasarkan Pasal 28 ayat (1) Undang-Undang Republik Indonesia Nomor 3 Tahun 2009 tentang Perubahan Kedua Atas Undang-Undang Nomor 14 Tahun 1985 tentang Mahkamah Agung (selanjutnya disebut UU No. 3 Tahun 2009), mengatur bahwa Mahkamah Agung bertugas dan berwenang memeriksa dan memutus:
a. permohonan kasasi;
b. sengketa tentang kewenangan mengadili;
c. permohonan peninjauan kembali putusan Pengadilan yang telah memperoleh kekuatan hukum tetap.

Berdasarkan Pasal 30 ayat (1) UU No. 3 Tahun 2009, mengatur bahwa Mahkamah Agung dalam tingkat kasasi membatalkan putusan atau penetapan pengadilan-pengadilan dari semua lingkungan peradilan karena:

a. tidak berwenang atau melampaui batas wewenang;

b. salah menerapkan atau melanggar hukum yang berlaku;

c. lalai memenuhi syarat-syarat yang diwajibkan oleh peraturan perundang-undangan yang mengancam kelalaian itu dengan batalnya putusan yang bersangkutan.

Berdasarkan Pasal 31 UU No. 3 Tahun 2009, mengatur bahwa:

(1) Mahkamah Agung mempunyai wewenang menguji peraturan perundang-undangan di bawah undang-undang terhadap undangundang.

(2) Mahkamah Agung menyatakan tidak sah peraturan perundangundangan di bawah undang-undang atas alasan bertentangan dengan peraturan perundang-undangan yanglebih tinggi atau pembentukannya tidak memenuhi ketentuan yang berlaku.

(3) Putusan mengenai tidak sahnya peraturan perundang-undangan sebagaimana dimaksud pada ayat (2) dapat diambil baik berhubungan dengan pemeriksaan pada tingkat kasasi maupun berdasarkan permohonan langsung pada Mahkamah Agung.

(4) Peraturan perundang-undangan yang dinyatakan tidaksah sebagaimana dimaksud pada ayat (3) tidak mempunyai kekuatan hukum mengikat.

Berdasarkan Pasal 32 UU No. 3 Tahun 2009, mengatur bahwa:

(1) Mahkamah Agung melakukan pengawasan tertinggi terhadap penyelenggaraan peradilan pada semua badan peradilan yang berada di bawahnya dalam menyelenggarakan kekuasaan kehakiman. 
(2) Selain pengawasan sebagaimana dimaksud pada ayat (1), Mahkamah Agung melakukan pengawasan tertinggi terhadap pelaksanaan tugas administrasi dan keuangan.

(3) Mahkamah Agung berwenang untuk meminta keterangan tentang hal-hal yang bersangkutan dengan teknis peradilan dari semua badan peradilan yang berada di bawahnya.

(4) Mahkamah Agung berwenang memberi petunjuk, teguran, atau peringatan kepada pengadilan di semua badan peradilan yang berada di bawahnya.

(5) Pengawasan dan kewenangan sebagaimana dimaksud pada ayat (1), ayat (2), ayat (3), dan ayat (4) tidak boleh mengurangi kebebasan hakim dalam memeriksa dan memutus perkara.

Berdasarkan Pasal 33 UU No. 3 Tahun 2009, mengatur bahwa:

(1) Mahkamah Agung memutus pada tingkat pertama dan terakhir semua sengketa tentang kewenangan mengadili:

a. antara Pengadilan di lingkungan Peradilan yang satu dengan Pengadilan di Lingkungan Peradilan yang lain;

b. antara dua Pengadilan yang ada dalam daerah hukum Pengadilan Tingkat Banding yang berlainan dari Lingkungan Peradilan yang sama;

c. antara dua Pengadilan Tingkat Banding di Lingkungan Peradilan yang sama atau antara lingkungan Peradilan yang berlainan.

(2) Mahkamah Agung berwenang memutus dalam tingkat pertama dan terakhir, semua sengketa yang timbul karena perampasan kapal asing dan muatannya oleh kapal perang Republik Indonesia berdasarkan peraturan yang berlaku.

Berdasarkan Pasal 34 UU No. 3 Tahun 2009, mengatur bahwa:

"Mahkamah Agung memeriksa dan memutus permohonan peninjauan kembali pada tingkat pertama dan terakhir atas putusan Pengadilan yang telah memperoleh kekuatan hukum tetap berdasarkan alasanalasan yang diatur dalam Bab IV Bagian Keempat Undang-undang ini."

Berdasarkan Pasal 35 UU No. 3 Tahun 2009, mengatur bahwa:

"Mahkamah Agung memberikan pertimbangan hukum kepada Presiden dalam permohonan grasi dan rehabilitasi."

Berdasarkan Pasal 45A UU No. 3 Tahun 2009, mengatur bahwa:

(1) Mahkamah Agung dalam tingkat kasasi mengadili perkara yang memenuhi syarat untuk diajukan kasasi, kecuali perkara yang oleh Undang-Undang ini dibatasi pengajuannya. 
(2) Perkara yang dikecualikan sebagaimana dimaksud pada ayat (1) terdiri atas:

a. putusan tentang praperadilan;

b. perkara pidana yang diancam dengan pidana penjara paling lama 1 (satu) tahun dan/atau diancam pidana denda;

c. perkara tata usaha negara yang objek gugatannya berupa keputusan pejabat daerah yang jangkauan keputusannya berlaku di wilayah daerah yang bersangkutan.

(3) Permohonan kasasi terhadap perkara sebagaimana dimaksud pada ayat (2) atau permohonan kasasi yang tidak memenuhi syarat-syarat formal, dinyatakan tidak dapat diterima dengan penetapan ketua pengadilan tingkat pertama dan berkas perkaranya tidak dikirimkan ke Mahkamah Agung.

(4) Penetapan ketua pengadilan sebagaimana dimaksud pada ayat (3) tidak dapat diajukan upaya hukum.

(5) Pelaksanaan ketentuan sebagaimana dimaksud pada ayat (3) dan ayat (4) diatur lebih lanjut oleh Mahkamah Agung.

\section{b. UU No. 48 Tahun 2009 tentang Kekuasaan Kehakiman}

Berdasarkan Pasal 20 UU No. 48 Tahun 2009, mengatur bahwa:

(1) Mahkamah Agung merupakan pengadilan negara tertinggi dari badan peradilan yang berada di dalam keempat lingkungan peradilan sebagaimana dimaksud dalam Pasal 18.

(2) Mahkamah Agung berwenang:

a. mengadili pada tingkat kasasi terhadap putusan yang diberikan pada tingkat terakhir oleh pengadilan di semua lingkungan peradilan yang berada di bawah Mahkamah Agung, kecuali undangundang menentukan lain;

b. menguji peraturan perundang-undangan di bawah undang-undang terhadap undang-undang; dan

c. kewenangan lainnya yang diberikan undang-undang.

(3) Putusan mengenai tidak sahnya peraturan perundang-undangan sebagai hasil pengujian sebagaimana dimaksud pada ayat (2) huruf b dapat diambil baik berhubungan dengan pemeriksaan pada tingkat kasasi maupun berdasarkan permohonan langsung pada Mahkamah Agung.

\section{c. UU No. 8 Tahun 1981 tentang Hukum Acara Pidana}

Berdasarkan Pasal 88 UU No. 8 Tahun 1981, mengatur bahwa "Mahkamah Agung berwenang mengadili semua perkara pidana yang dimintakan kasasi”. Dari ketentuan di atas, pada hakekatnya asas dan tujuan keberadaan 
Mahkamah Agung terkait permohonan upaya hukum kasasi adalah untuk menjamin persamaan di hadapan hukum. Olehnya itu, maka setiap permohonan upaya hukum kasasi juga harus memiliki alasan yang jelas, sebagaimana berdasarkan Pasal 30 ayat (1) UU No. 3 Tahun 2009 yang telah disebutkan sebelumnya, dan berdasarkan Pasal 253 ayat (1) UU No. 8 Tahun 1981, yang mengatur bahwa pemeriksaan dalam tingkat kasasi dilakukan oleh Mahkamah Agung atas permintaan para pihak sebagaimana dimaksud dalam Pasal 244 dan Pasal 249 guna menentukan:

a. apakah benar suatu peraturan hukum tidak diterapkan atau diterapkan tidak sebagaimana mestinya;

b. apakah benar cara mengadili tidak dilaksanakan menurut ketentuan undang-undang;

c. apakah benar pengadilan telah melampaui batas wewenangnya.

Adapun permohonan upaya hukum kasasi terdiri dari dua syarat. Pertama, syarat formal, sebagaimana berdasarkan Pasal 245 UU No. 8 Tahun 1981, mengatur bahwa:

(1) Permohonan kasasi disampaikan oleh pemohon kepada panitera pengadilan yang telah memutus perkaranya dalam tingkat pertama, dalam waktu empat belas hari sesudah putusan pengadilan yang dimintakan kasasi itu diberitahukan kepada terdakwa.

(2) Permintaan tersebut oleh panitera ditulis dalam sebuah surat keterangan yang ditandatangani oleh panitera serta pemohon, dan dicatat dalam daftar yang dilampirkan pada berkas perkara.

(3) Dalam hal pengadilan negeri menerima permohonan kasasi, baik yang diajukan oleh penuntut umun, atau terdakwa maupun yang diajukan oleh penuntut umum dan terdakwa sekaligus, maka panitera wajib memberitahukan permintaan dari pihak yang satu kepada pihak yang lain.

Berdasarkan Pasal 246 UU No. 8 Tahun 1981, mengatur bahwa:

(1) Apabila tenggang waktu sebagaimana dimaksud dalam Pasal 245 ayat (1) telah lewat tanpa diajukan permohonan kasasi oleh yang bersangkutan, maka yang bersangkutan dianggap menerima putusan.

(2) Apabila dalam tenggang waktu sebagaimana dimaksud dalam ayat (1), pemohon terlambat mengajukan permohonan kasasi maka hak untuk itu gugur.

(3) Dalam hal sebagaimana dimaksud dalam ayat (1) atau ayat (2), maka panitera, mencatat dan membuat akta mengenai hal itu serta melekatkan akta tersebut pada berkas perkara. 
Kedua, syarat materiil, sebagaimana berdasarkan Pasal 253 ayat (1) UU No. 8 Tahun 1981 yang telah disebutkan sebelumnya.

Dalam hal ini Mahkamah Agung adalah Judex Juris, artinya Mahkamah Agung hanya sebatas memeriksa apakah putusan pengadilan itu telah sesuai atau bertentangan dengan hukum, sehingga yang diperiksa di tingkat kasasi adalah penerapan hukumnya saja. Berikut putusan yang dapat diajukan upaya hukum kasasi, antara lain yaitu;

1) Pemidanaan;

2) Pembebasan;

3) Lepas dari segala tuntutan hukum;

4) Putusan dalam acara pidana lalu lintas berupa pidana denda.

Adapun putusan yang tidak dapat diajukan upaya hukum kasasi adalah putusan Praperadilan, apapun jenis putusannya.

\section{B. Upaya Hukum Luar Biasa}

\section{Pemeriksaan Kasasi demi Kepentingan Hukum}

Penegak hukum hanya melakukan pemeriksaan kasasi untuk kepentingan hukum, dalam hal ini kewenangan Jaksa Agung, bukan tersangka maupun terpidana. ${ }^{25}$ Artinya, upaya hukum ini hanya mengatur upaya-upaya yang dilakukan kejaksaan.

\section{Peninjauan Kembali}

Peninjauan kembali adalah bentuk upaya hukum luar biasa yang diberikan kepada pihak yang mencari keadilan. ${ }^{26}$ Peninjauan kembali diajukan untuk melawan suatu putusan pidana yang telah berkekuatan hukum tetap, dan hanya dapat diajukan oleh terpidana atau ahli warisnya. Selaras dengan pandangan Adami Chazawi, bahwa: ${ }^{27}$

"Putusan yang dapat dimintakan upaya hukum peninjauan kembali adalah putusan yang telah berkekuatan hukum tetap, bukan merupakan putusan bebas atau lepas dari tuntutan hukum, dan pihak yang mengajukan adalah terpidana atau ahli warisnya."

Peninjauan Kembali adalah upaya hukum yang dilakukan oleh terpidana yang merasa bahwa hukuman yang dijatuhkan adalah salah, sehingga terpidana mengajukan permohonan agar perkaranya dapat ditinjau kembali. Olehnya

\footnotetext{
${ }^{25}$ Rendi Renaldi Mumbunan. (2018). Upaya Hukum Biasa dan Luar Biasa terhadap Putusan Hakim dalam Perkara Pidana. Lex Crimen: Jurnal Elektronik Bagian Hukum Pidana, Universitas Sam Ratulangi, 7(10), hlm. 43.

${ }^{26}$ Ahmad Fauzi. (2014). Analisis Yuridis terhadap Upaya Hukum Luar Biasa Peninjauan Kembali (PK) oleh Jaksa dalam Sistem Hukum Acara Pidana Indonesia. Jurnal Hukum dan Peradilan, Mahkamah Agung RI, 3(1), hlm. 41.

${ }^{27}$ Adami Chazawi. (2010). Lembaga Peninjauan Kembali (PK) Perkara Pidana: Penegakan Hukum dalam Penyimpangan Praktik \& Peradilan Sesat. Jakarta: Sinar Grafika, hlm. 1.
} 
itu, berdasarkan Pasal 263 UU No. 8 Tahun 1981, mengatur bahwa:

(1) Terhadap putusan pengadilan yang telah memperoleh kekuatan hukum tetap, kecuali putusan bebas atau lepas dari segala tuntutan hukum, terpidana atau ahli warisnya dapat mengajukan permintaan peninjauan kembali kepada Mahkamah Agung.

(2) Permintaan peninjauan kembali dilakukan atas dasar:

a. apabila terdapat keadaan baru yang menimbulkan dugaan kuat, bahwa jika keadaan itu sudah diketahui pada waktu sidang masih berlangsung, hasilnya akan berupa putusan bebas atau putusan lepas dari segala tuntutan hukum atau tuntutan penuntut umum tidak dapat diterima atau terhadap perkara itu diterapkan ketentuan pidana yang lebih ringan;

b. apabila dalam pelbagai putusan terdapat pernyataan bahwa sesuatu telah terbukti, akan tetapi hal atau keadaan sebagai dasar dan alasan putusan yang dinyatakan telah terbukti itu, ternyata telah bertentangan satu dengan yang lain;

c. apabila putusan itu dengan jelas memperlihatkan suatu kekhilafan hakim atau suatu kekeliruan yang nyata.

(3) Atas dasar alasan yang sama sebagaimana tersebut pada ayat (2) terhadap suatu putusan pengadilan yang telah memperoleh kekuatan hukum tetap dapat diajukan permintaan peninjauan kembali apabila dalam putusan itu suatu perbuatan yang didakwakan telah dinyatakan terbukti akan tetapi tidak diikuti oleh suatu pemidanaan.

Adapun peraturan perundang-undangan terkait upaya hukum peninjauan kembali, antara lain sebagai berikut.

1. Pasal 263 sampai dengan Pasal 269 UU No. 8 Tahun 1981;

2. Pasal 23 UU No. 48 Tahun 2009;

3. Pasal 60 sampai dengan Pasal 76 UU No. 3 Tahun 2009.

\section{KESIMPULAN DAN SARAN}

Berdasarkan uraian hasil dan pembahasan, maka dapat disimpulkan bahwa upaya hukum bagi para terdakwa atau terpidana sebagai bentuk persamaan di hadapan hukum berdasarkan peraturan perundang-undangan, terdiri dari upaya hukum biasa dan upaya hukum luar biasa. Adapun upaya hukum biasa, meliputi perlawanan, banding, dan kasasi. Sedangkan upaya hukum luar biasa, meliputi pemeriksaan kasasi demi kepentingan hukum dan peninjauan kembali. Upaya hukum juga merupakan manifestasi dari fungsi hukum, dimana untuk melindungi manusia dalam masyarakat, bangsa, dan negara. Selain itu baik jiwa dan raga maupun hak individu yaitu hak asasinya, hak kebendaanya, maupun hak perorangannya. Dengan dasar kesimpulan tersebut, disarankan agar baik aparat penyelenggara hukum maupun masyarakat, 
khususnya para pelaku tindak pidana agar memahami hak dan kewajiban yang telah diatur dalam UU No. 8 Tahun 1981, UU No. 3 Tahun 2009, dan UU No. 48 Tahun 2009 terkait perlindungan hukum terhadap pelaku tindak pidana berdasarkan sistem peradilan pidana Indonesia.

\section{REFERENSI}

A. Adiwana \& Amalia Zakiyatu Faturrahmah. (2016). Argumentasi Penuntut Umum Mengajukan Kasasi terhadap Putusan Bebas Pengadilan Negeri Yogyakarta dalam Tindak Pidana Perbuatan Merugikan Pemiutang (Studi Putusan Mahkamah Agung Nomor 601K/PID/2013). Verstek, Universitas Sebelas Maret, 5(1), hlm. $1-13$.

Adami Chazawi. (2010). Lembaga Peninjauan Kembali (PK) Perkara Pidana: Penegakan Hukum dalam Penyimpangan Praktik \& Peradilan Sesat. Jakarta: Sinar Grafika.

Agus Maksum Mulyohadi. (2015). Disparitas Pidana Putusan Hakim atas Perkara Pidana Anak dalam Perspektif Perlindungan Hak-Hak Anak (Studi Kasus Pengadilan Negeri Boyolali Tahun 2009 - 2013). Jurnal Jurisprudence, Universitas Muhammadiyah Surakarta, 5(2), hlm. 127-136.

Ahmad Fauzi. (2014). Analisis Yuridis terhadap Upaya Hukum Luar Biasa Peninjauan Kembali (PK) oleh Jaksa dalam Sistem Hukum Acara Pidana Indonesia. Jurnal Hukum dan Peradilan, Mahkamah Agung RI, 3(1), hlm. 37-48. doi: http://dx.doi. org/10.25216/jhp.3.1.2014.37-48

Bilryan Lumempouw. (2013). Hak Terdakwa Melakukan Upaya Hukum dalam Proses Peradilan Pidana. Lex Crimen: Jurnal Elektronik Bagian Hukum Pidana, Universitas Sam Ratulangi, 2(3), hlm. 185-195.

Christian Hadinata Tamusala. (2018). Upaya Hukum Kasasi terhadap Tindak Pidana Korupsi Menurut Undang-Undang Pokok Kekuasaan Kehakiman Nomor 48 Tahun 2009. Lex Crimen: Jurnal Elektronik Bagian Hukum Pidana, Universitas Sam Ratulangi, 7(4), hlm. 104-111.

Enrico Simanjuntak. (2013). Kewenangan Hak Uji Materil pada Mahkamah Agung RI. Jurnal Hukum dan Peradilan, Mahkamah Agung RI, 2(3), hlm. 337-356. doi: http://dx.doi.org/10.25216/jhp.2.3.2013.337-356

Fajar Laksono Soeroso. (2014). Aspek Keadilan dalam Sifat Final Putusan Mahkamah Konstitusi. Jurnal Konstitusi, Mahkamah Konstitusi RI, 11(1), hlm. 64-84.

Gabriela K. Kaawoan. (2017). Perlindungan Hukum terhadap Terdakwa dan Terpidana sebagai Pelaku Tindak Pidana Pembunuhan. Lex Administratum, Universitas Negeri Semarang, 5(1), hlm. 125-131.

Harold Joseph Berman (Ed.) (1961). Talks on American Law: A Series of Broadcasts to Foreign Audiences by Members of the Harvard Law School Faculty. New York: Vintage Books.

Heru Santosa. (2011). Ancaman terhadap Dasar Negara "Pancasila" bagi Rakyat Indonesia dalam Berbangsa dan Bernegara. Humanika: Kajian Ilmiah Mata Kuliah Umum, Universitas Negeri Yogyakarta, 11(2), hlm. 1-13. doi: https://doi. org/10.21831/hum.v11i1.20997 
Janpatar Simamora. (2014). Kepastian Hukum Pengajuan Kasasi oleh Jaksa Penuntut Umum terhadap Vonis Bebas. Jurnal Yudisial, Komisi Yudisial Republik Indonesia, 7(1), hlm. 1-17.

Luhut M. P. Pangaribuan. (2002). Hukum Acara Pidana: Surat-Surat Resmi di Pengadilan oleh Advokat Praperadilan, Eksepsi, Pledoi, Memori Banding, Kasasi, Peninjauan Kembali. Jakarta: Djambatan.

M. Yahya Harahap. (2006). Pembahasan Permasalahan dan Penerapan KUHAP: Penyidikan dan Penuntutan. Jakarta: Sinar Grafika.

M. Yahya Harahap. (2012). Pembahasan Permasalahan dan Penerapan KUHAP: Pemeriksaan Sidang Pengadilan, Banding, Kasasi dan Peninjauan Kembali (Edisi 2). Jakarta: Sinar Grafika.

N. Nasrullah. (2020). Putusan Hakim terhadap Pemberian Sanksi di Bawah Batas Minimal pada Tindak Pidana Narkotika. SIGn Jurnal Hukum, CV. Social Politic Genius (SIGn), 2(1), hlm. 1-19. doi: https://doi.org/10.37276/sjh.v2i1.59

Nurul Qamar \& Farah Syah Rezah. (2020). Metode Penelitian Hukum: Doktrinal dan Non-Doktrinal. Makassar: CV. Social Politic Genius (SIGn).

Osman Simanjuntak. (1995). Teknik Penuntutan dan Upaya Hukum. Jakarta: Grasindo.

Philipus M. Hadjon. (1987). Perlindungan Hukum Bagi Rakyat di Indonesia: Sebuah Studi tentang Prinsip-Prinsipnya, Penanganannya oleh Peradilan dalam Lingkungan Peradilan Umum dan Pembentukan Peradilan Administrasi Negara. Surabaya: PT. Bina Ilmu.

Prianter Jaya Hairi. (2011). Antara Prinsip Peradilan Sederhana, Cepat dan Berbiaya Ringan dan Gagasan Pembatasan Perkara Kasasi. Negara Hukum: Membangun Hukum untuk Keadilan dan Kesejahteraan, Pusat Penelitian Badan Keahlian DPR RI, 2(1), hlm. 151-178.

Priscilia Singal. (2013). Fungsi Lembaga Peninjauan Kembali dalam Sistem Peradilan Pidana di Indonesia. Lex et Societatis, Universitas Sam Ratulangi, 1(2), hlm. 106115.

Putra Halomoan Hsb. (2015). Tinjauan Yuridis tentang Upaya-Upaya Hukum. Yurisprudentia: Jurnal Hukum Ekonomi, Institut Agama Islam Negeri Padangsidimpuan, 1(1), hlm. 42-53.

Rendi Renaldi Mumbunan. (2018). Upaya Hukum Biasa dan Luar Biasa terhadap Putusan Hakim dalam Perkara Pidana. Lex Crimen: Jurnal Elektronik Bagian Hukum Pidana, Universitas Sam Ratulangi, 7(10), hlm. 40-47.

Rifandy Ritonga. (2016). Analisis Pengujian Pengaduan Konstitusional (Constitutional Complaint) pada Mahkamah Konstitusi Indonesia sebagai Salah Satu Upaya Perlindungan Hak-Hak Warga Negara. Keadilan Progresif, Universitas Bandar Lampung, 7(1), hlm. 1-16.

Syahrul Sitorus. (2018). Upaya Hukum dalam Perkara Perdata (Verzet, Banding, Kasasi, Peninjauan Kembali dan Derden Verzet). Hikmah, Sekolah Tinggi Agama Islam Sumatera, 15(1), hlm. 63-71. 
Syarif Saddam Rivanie. (2020). Pengadilan Internasional dalam Memberantas Tindak Pidana Terorisme: Tantangan Hukum dan Politik. Sovereign: Jurnal Ilmiah Hukum, CV. Social Politic Genius (SIGn), 2(3), hlm. 15-27. doi: https://doi.org/10.37276/ sjih.v2i3.36

Undang-Undang Dasar Negara Republik Indonesia Tahun 1945.

Undang-Undang Republik Indonesia Nomor 1 Tahun 1946 tentang Peraturan Hukum Pidana.

Undang-Undang Republik Indonesia Nomor 1 Tahun 1960 tentang Perubahan Kitab Undang-Undang Hukum Pidana. (Lembaran Negara Republik Indonesia Tahun 1960 Nomor 1. Tambahan Lembaran Negara Republik Indonesia Nomor 1921).

Undang-Undang Republik Indonesia Nomor 8 Tahun 1981 tentang Hukum Acara Pidana. (Lembaran Negara Republik Indonesia Tahun 1981 Nomor 76. Tambahan Lembaran Negara Republik Indonesia Nomor 3209).

Undang-Undang Republik Indonesia Nomor 14 Tahun 1985 tentang Mahkamah Agung. (Lembaran Negara Republik Indonesia Tahun 1985 Nomor 73. Tambahan Lembaran Negara Republik Indonesia Nomor 3316).

Undang-Undang Republik Indonesia Nomor 5 Tahun 2004 tentang Perubahan Atas Undang-Undang Nomor 14 Tahun 1985 tentang Mahkamah Agung. (Lembaran Negara Republik Indonesia Tahun 2004 Nomor 9. Tambahan Lembaran Negara Republik Indonesia Nomor 4359).

Undang-Undang Republik Indonesia Nomor 3 Tahun 2009 tentang Perubahan Kedua Atas Undang-Undang Nomor 14 Tahun 1985 tentang Mahkamah Agung. (Lembaran Negara Republik Indonesia Tahun 2009 Nomor 3. Tambahan Lembaran Negara Republik Indonesia Nomor 4958).

Undang-Undang Republik Indonesia Nomor 48 Tahun 2009 tentang Kekuasaan Kehakiman. (Lembaran Negara Republik Indonesia Tahun 2009 Nomor 157. Tambahan Lembaran Negara Republik Indonesia Nomor 5076).

Willy Widianto. (2010, 20 Oktober). PK Mantan Bupati Natuna Ditolak MA. Dalam Tribunnews.com. Diakses dari https://www.tribunnews.com/ nasional/2010/10/20/pk-mantan-bupati-natuna-ditolak-ma, pada tanggal 27 Desember 2020.

\footnotetext{
I Hasan Basri. (2021). Perlindungan Hukum terhadap Pelaku Tindak Pidana I ' berdasarkan Sistem Peradilan Pidana Indonesia. SIGn Jurnal Hukum, CV. Social Politic ! I Genius (SIGn), 2(2), hlm. 104-121. doi: https://doi.org/10.37276/sjh.v2i2.90

ᄂ _ _ _ _ _ _ _ _ _ _ _ _ _ _ _ _ _ _ _ _ _ _ _ _ _ . . _ .
} 